\title{
The Oslo People-to-People Program and the Limits of Hegemony
}

\section{Nadia Naser-Najjab}

To cite this article: Nadia Naser-Najjab (2019): The Oslo People-to-People Program and the Limits of Hegemony, Middle East Critique, DOI: 10.1080/19436149.2019.1664797

To link to this article: https://doi.org/10.1080/19436149.2019.1664797

曲 Published online: 17 Sep 2019.

Submit your article to this journal ๘

Q View related articles $₫$

View Crossmark data \lceil 


\title{
The Oslo People-to-People Program and the Limits of Hegemony
}

\author{
NADIA NASER-NAJJAB \\ University of Exeter, Exeter, UK
}

\begin{abstract}
Reconciliation-based initiatives evoke a substantive and meaningful vision of peace and suggest a form of peace building that is intimately engaged at the personal and social level. This article critically engages with a specific reconciliation initiative, the People-to-People Program (P2PP) that was applied to the Palestinian-Israeli conflict. It uses Gramscian concepts of hegemony, consent, and war of position, with the intention of illustrating that the program functioned as a disciplinary or regulatory device that structured and realigned the agency of its Palestinian participants. In highlighting the different features and dimensions of Palestinian subversion and resistance, it brings out the limits of hegemony.
\end{abstract}

Key Words: Civil society; Diplomacy; Hegemony; Oslo Accords; Peace-building; People-toPeople program (P2PP); Settler colonialism

The People-to-People program is a form of second-track diplomacy that was put in place by the 1995 Oslo II Agreement. ${ }^{1}$ Its implementation contributed to the fragmentation of the Occupied Palestinian territories (OPT) and the events of 2007, when HAMAS launched a coup in response to the Palestinian Authority (PA)'s failure to recognize the results of the 2006 legislative elections. The Gaza-West Bank divide has continued both to symbolize and reinforce Palestinian schisms. ${ }^{2}$

The Oslo Agreement also created enclaves ${ }^{3}$ that restricted Palestinian movement. ${ }^{4}$ After 1993, when the Agreement came into effect, construction of Israeli settlements

Correspondence Address: Nadia Naser-Najjab, Institute of Arab and Islamic Studies, University of Exeter, Stocker Road, Exeter EX4 4ND, UK. Email: n.naser-najjab@exeter.ac.uk

${ }^{1}$ Oslo II addressed issues of self-rule, established the Palestinian Authority (PA) and divided the West Bank into three areas (Area A, which accounted for four percent of the West Bank, was allocated to the PA; Area B, which was under joint Israeli and PA administration, accounted for 27 percent; and Area C, which was under full Israeli control, accounted for 69 percent). The status of Jerusalem and other 'final status' issues, were excluded from this agreement; see Raja Shehadeh (1997) From Occupation to Interim Accords: Israeli and the Palestinian Territories, p. 71.

${ }^{2}$ See, for example, As'ad Ghanem (2010) Palestinian Politics After Arafat: A Failed National Movement (Bloomington: Indiana University Press); and Jamil Hilal (2010) The Polarization of the Palestinian Political Field, Journal of Palestine Studies, 39(3), pp. 24-39.

${ }^{3}$ Leila Farsakh (2005) Independence, Cantons or Bantustans: Whither the Palestinian State?, Middle East Journal, 59(2), p. 238.

${ }^{4}$ Sara Roy (1995) The Gaza Strip: The Political Economy of De-Development, p. 117 (Washington, DC: Institute for Palestinian Studies).

(C) 2019 Editors of Middle East Critique 
increased by 53 percent. $^{5}$ Israel's creation of by-pass roads that connected these settlements, enabling it to tighten its grip on Palestinian land and population brought about further fragmentation. ${ }^{6}$ These activities were key contributing factors to the Al-Aqsa Intifada, which broke out in September $2000 .^{7}$ In response to this popular uprising, Israel launched a full military operation against the PA and Palestinians. Roadblocks were put in place, along with closures and other restrictions on Palestinian movement. ${ }^{8}$ In 2002, work began on the so-called 'separation wall,' which cuts through Palestinian land, further reinforcing a general condition of fragmentation. ${ }^{9}$

Within this context Israel continues to expand its control and power. Far from addressing this development, no agreements or initiatives ${ }^{10}$ have addressed crucial issues related to Palestinian rights and sovereignty. On the contrary, arrangements such as the 1994 Paris Protocols, under which Israel collects tax revenues on behalf of the PA, actually reinforce Israeli control. ${ }^{11}$ Israel also exerts power through economic development and the dependency that has emerged as a consequence of reliance on aid. ${ }^{12}$ As a consequence of Oslo II, international donors have assumed a prominent role in peace-building and state-building interventions within the OPT. ${ }^{13}$ The professionalization of Palestinian society has been an important accompaniment to this development, as Rema Hammami acknowledged: ' ... [M] any [formerly] popularly-based grass-roots initiatives [became] professionally-based, foreign-funded development centres which targeted clients as opposed to working with a constituency. ${ }^{14}$ The P2PP was in many respects an outgrowth of this development. ${ }^{15}$

Sceptical observers such as Adam Hanieh claim that such projects represent an 'attempt to incorporate Israeli colonialism into the very practice of development itself., 16

${ }^{5}$ Peace Now (2000) Summary Data, 4 December 2000; and Palestinian Academic Society for the Study of International Affairs (PASSIA) (2001) Settlements and the Final Status Talks, Special Bulletin, March, Jerusalem/Al-Quds.

${ }^{6}$ Eyal Weizman (2007) Hollow Land: Israel's Architecture of Occupation (London: Verso Books); and Emile Badarin (2015) Settler-Colonialist Management of Entrances to the Native Urban Space in Palestine, Settler Colonial Studies, 5(3), p. 5.

${ }^{7}$ Marwan Bishara (2001) Palestine/Israel: Peace or Apartheid: Prospects for Resolving the Conflict, $\mathrm{p}$. 56 (Zed Books, London).

${ }^{8}$ Saree Makdisi (2010) Palestine Inside Out: An Everyday Occupation (New York: Norton).

${ }^{9}$ B'Tselem (2010) By Hook and By Crook: Israel's Settlement Policy in the West Bank, Summary. Jerusalem: 5 July; and World Bank (2011) Coping with Conflict: Poverty and Inclusion in the West Bank and Gaza (Washington: The World Bank Group).

${ }^{10}$ For example, the regional Arab Peace Initiative that Crown Prince Abdullah Bin Abdullaziz of Saudi Arabia proposed in March 2002; later initiatives followed.

${ }^{11}$ Adel Zagha \& Husam Zumlot (2004) Israel and the Palestinian economy: Integration or Containment?, in: Mushtaq Husain Khan, George Giacaman \& Inge Amundsen (eds) State Formation in Palestine: Viability and Governance During a Social Transformation (London: Routledge).

${ }^{12}$ Rashid Khalidi (2006) The Iron Cage: The Story of the Palestinian Struggle for Statehood (Boston: Beacon Press); and Toufic Haddad (2016) Palestine Ltd: Neoliberalism and Nationalism in the Occupied Territories, p. 102 (London: I. B. Taurus)

${ }^{13}$ Haddad, Palestine Ltd, p. 2.

${ }^{14}$ Rema Hammami (1995) NGOs: The Professionalization of Politics, Race \& Class, 37(2), p. 55.

${ }^{15}$ Raja Khalidi \& Samour Sobhi (2011) Neoliberalism as Liberation: The Statehood Program and the Remaking of the Palestinian National Movement, Journal of Palestine Studies, 40(2), p. 15.

${ }^{16}$ Adam Hanieh (2016) Development as Struggle: Confronting the Reality of Power in Palestine, Journal of Palestine Studies, 45(4), p. 35; also see Taiaiake Alfred (2005) Wasáse: Indigenous Path ways of Actions and Freedom (Peterborough, Ontario: Broadview Press), p. 35. 
In a context defined by deeply unequal power relations, 'cooperation' takes on a very different meaning and implication. As Jan Selby notes (albeit with reference to the distribution and usage of water resources): 'Much of what had previously been patron-client relations under occupation were suddenly discursively repackaged and represented as instances of Israeli-Palestinian 'co-operation. ${ }^{, 17}$

In this article I offer a critical reading that does not engage with the question of implementation. Instead, it draws on contributions from Antonio Gramsci, Michel Foucault and the critical peace-building literature to illustrate how one should engage with the P2PP and understand it as a 'technology of government' that subtly reformulates and reorders. In considering this point, I also will bring out themes of Palestinian resistance and subversion.

\section{Methodology}

My extensive experience as an organizer, coordinator and participant in P2PP activities between 1995 and 2000 is incorporated into this article. In summer 2001, as part of my doctoral dissertation research, I engaged with the P2PP through a series of open, semi-structured and structured interviews with (Israeli and Palestinian) coordinators, participants and officials. I conducted additional interviews and research project fieldwork during 2003. In conducting the interviews, I had to overcome numerous obstacles. The most obvious was the Al-Aqsa Intifada, which, in combination with the Israeli army's repressive measures, imposed considerable limitations on my freedom of movement between the West Bank's towns and villages and restricted my entry into Israel and Jerusalem. While the vast majority of interviews were conducted face-toface, some were carried out via telephone.

My Palestinian nationality and my previous participation within the P2PP enabled me to establish a rapport with interviewees and to form contacts (interviews with Israelis were facilitated by an Israeli coordinator). It also made it easier for me to access required information and data sources. Being a Palestinian researcher has helped me to understand how the perspective of the dominant actor and the absence of an analysis of power relations can skew 'neutrality. ${ }^{18}$ I therefore was able to 'propos[e] solutions to the real-life dilemmas that indigenous communities confront." ${ }^{19}$ My status as a Palestinian also has helped me to understand how research can be a form of resistance directed towards the structures and tactics of colonization. ${ }^{20}$

\section{The P2P Program}

The P2PP brought a certain coherence to contact between Israelis and Palestinians, creating an institutionalization and sense of purpose that was previously absent. It was not a stand-alone initiative, the intention being to feed into wider peace-building

\footnotetext{
${ }^{17}$ Jan Selby (2003) Dressing up Domination as 'Cooperation': The Case of Israeli-Palestinian Water Relations, Review of International Studies, 29 (1), p. 123.

${ }^{18}$ Ismael Abu-Saad (2008) Where inquiry ends: The peer review process and indigenous standpoints, American Behavioral Scientist, 51, p. 1914.

${ }^{19}$ Linda Tuhiwai Smith (2012) Decolonizing Methodologies (London: Zed Books), p. 151.

${ }^{20}$ Sandy Grande (2004) Red Pedagogy: Native American Social and Political Thought, p. 30 (Lanham, MD: Rowman \& Littlefield Publishers).
} 
enterprises. $^{21}$ Article VIII (The People-to-People Program) of Annex VI (Protocol Concerning Israeli- Palestinian Co-operation Program) of Oslo II, states:

1. The two sides shall cooperate in enhancing the dialogue and relations between their peoples in accordance with the concepts developed in co-operation with the Kingdom of Norway.

2. The two sides shall cooperate in enhancing dialogue relations between their peoples, as well as in gaining a wider exposure of the two publics to the peace process, its current situation and predicted results.

3. The two sides shall take steps to foster public debate and involvement, to remove barriers to interaction, and to increase the people to people exchange and interaction within all areas of cooperation ... ${ }^{22}$

The $\mathrm{P} 2 \mathrm{PP}^{23}$ expressed a strong belief in the benefits of civil society engagement and mobilization. It emphasized the importance of removing obstacles to contact (Article VIII of Annex VI of Oslo II) and sought to establish a neutral and unthreatening space in which social actors - a privileged role was afforded to Private and Voluntary Organisations (PVOs) and Non-Government Organisations (NGOs) - could pursue their personal and social interests. It maintained that contact would dissolve preconceptions and prejudices and establish a clear space within which mutual interests could be identified and developed (here it should be noted that 'contact' was theorized at a psychological or interpersonal level and little or no reference was made to the wider 'framing' context-see below).

The P2PP's structure was set out in Article III (Annex VI) of Oslo II. This established a Standing Cooperation Committee (SCC) that brought together Israeli and Palestinian representatives to co-ordinate activities and projects. Initially, it was funded by the Norwegian Ministry of Foreign Affairs and later was supported by a range of institutional donors, including the European Union, USAID and the Canada Fund. The Norwegian Foreign Ministry was represented on the P2PP's steering committee (a privilege denied to other donors) and was also accorded a pre-eminent political role. ${ }^{24}$ The Norwegian Fafo Institute for Applied Social Science Centre for International Studies in Oslo (subsequently Fafo) was responsible for coordinating with Israeli participants and Palestinian planning groups.

The political and popular components were established with the clear expectation that they would be interdependent. However, this initial aspiration was frustrated from the outset by Palestinian officials, who objected that it lacked a supporting consensus.

${ }^{21}$ Dimitris Bouris (2010) The European Union's Role in the Palestinian Territory after the Oslo Accords: Stillborn State-building, Journal of Contemporary European Research, 6 (3), pp. 376-394. Available at: http://www.jcer.net/ojs/index.php/jcer/article/view/205/232, accessed February 2, 2019; Khalidi \& Sobhi, 'Neoliberalism as Liberation;' and Haddad, Palestine Ltd.

22 Jerusalem Media and Communication Center (JMCC) (1996) Israeli-Palestinian Interim Agreement on the West Bank and the Gaza Strip (1995), p. 227 (Washington DC: Occasional Document Series, No. 7, August).

${ }^{23}$ This article clearly distinguishes between the P2P program (established by the Oslo II Agreement) and the voluntary joint activities prior to the Oslo II Agreement.

${ }^{24}$ Lena Endresen \& Signe Gilen (2000) Consultation and Consensus: Implementing the Israeli-Palestinian People-to-People Program for Development, Development: Journal of the Society for International Development, 43(3), pp. 29-33; and Lena Endresen (2001) Contact and Cooperation: The IsraeliPalestinian People-to-People Program (Oslo: Institute for Applied Social Science). 
Hassan Abu-Libedeh, ${ }^{25}$ who developed the concept of the P2PP during the Oslo negotiations, further clarified the Palestinian opposition; he noted:

[T] he Palestinian reading of the Oslo Agreement is absent while the Israeli one has remained dominant. P2P for Palestinians is supposed to be a strategic goal and a real investment in raising Israeli public opinion on the Palestinian political position and perceptions of the Oslo Agreement. ${ }^{26}$

Other key Palestinian institutions also rejected the P2PP, on the basis that the prevailing occupation made it impossible for Israelis and Palestinians to engage on equal terms. This was the position of both Birzeit University and the Palestinian Ministry of Education.

In addition to being substantially weakened by the conscious disengagement of political and civil society actors (although it should be recognized that individuals did sometimes otherwise engage), the conceptual and theoretical foundations of the P2PP also were strikingly disconnected from the local context. This was most clearly evident in the fact that it failed to acknowledge, much less engage with, a pre-existent tradition of contact. ${ }^{27}$ During the First Intifada, Israelis and Palestinian activists had united in opposition to the occupation, with Israeli peace activists often being subjected to the same brutal treatment as their Palestinian counterparts. ${ }^{28}$

The limitations of the P2PP were not entirely internal (e.g., related to the internal arrangement and structure of the P2PP) but also derived from an external environment that had been created, in large part, by the Oslo Agreement. This environment often became a topic of discussion during P2PP activities. However, the P2PP had a limited ability to engage with this wider reality precisely because it was based on the assumption - shared by Israeli participants - that cooperation would be strengthened through the establishment of personal relationships and professional cooperation. Despite its questionable relationship to the Palestinian-Israeli conflict, prominent donors and international actors continued to evidence an abiding faith in the potential of the P2PP. ${ }^{29}$

The EU alone, as the largest international donor currently engaged with the conflict, ${ }^{30}$ contributed an annual total of between $€ 5-10$ million to P2P-related activities

\footnotetext{
${ }^{25}$ Author Interview, Hassan Abu-Libedeh, Ramallah, October 19, 2003. Hassan Abu-Libedeh worked for the Palestinian Central Bureau of Statistics when I interviewed him. In 2019 he was the Minister/Chief of Staff in the Prime Minister's Office.

${ }^{26}$ Ibid.

${ }^{27}$ Reuven Kaminer (1996) Politics of Protest: The Israeli Peace Movement and the Palestinian Intifada (Brighton: Sussex Academic Press); Mazin Qumsiyeh (2012) Popular Resistance in Palestine: A History of Hope and Empowerment (London: Pluto Press); and Marwan Darweish \& Andrew Rigby (2015) Popular Protest in Palestine: The Uncertain Future of Unarmed Resistance (London: Pluto Press).

${ }^{28}$ Mordechai Bar-On (1996) In Pursuit of Peace: A History of the Israeli Peace Movement (Washington, DC: United States Institute of Peace Press), p. 227.

${ }^{29}$ Naseef Mu'allem (1999) Palestinian Israeli Civil Society Co-operative Activities,paper presented at Peace Building between Israelis and Palestinians workshop, Helsinki, November 27-28; Paul Scham (2000) Arab-Israeli research cooperation, 1995-1999, Middle East Review of International Affairs Journal, 4(3), pp. 1-16; Sari Hanafi (2007) Dancing Tango During Peace-building: Palestinian-Israeli People-to-People Programs for Conflict Resolution, in: Judy Kuriansky, Beyond Bullets \& Bombs; and Grassroots Peacebuilding between Israelis and Palestinians, pp. 69-80 (Westport, CT: Praeger).

${ }^{30}$ Bouris, The European Union's Role.
} 
(exemplified by the EU's Partnership for Peace Program (PFP) ${ }^{31}$ and Peace-building Initiative). In the years subsequent to 2008, the US government contributed an annual total of around $\$ 10$ million to P2P activities, ${ }^{32}$ with USAID's Conflict Management and Mitigation Program being a case-in-point. This support has been accompanied by a sustained reluctance to engage with the root causes of the conflict or its colonial dimensions. In 2008, to take one example, the EU yielded to pro-Israeli pressure and withdrew funding for the Israeli Committee against House Demolition (ICAHD). ${ }^{33}$

\section{Theoretical Framework}

The P2PP was deeply indebted to classical contact theory and the work of social psychologists such as Gordon Allport (1954), ${ }^{34}$ Stuart Cook (1962), ${ }^{35}$ Yehuda Amir (1969) ${ }^{36}$ and Thomas Pettigrew (1971). ${ }^{37}$ It also incorporated later innovations in the field, such as Social Identity Theory (SIT), which had been developed by Henri Tajfel $(1974)^{38}$ and John Turner (1979), ${ }^{39}$ largely in response to the limitations of the contact hypothesis. SIT attempts to gain insight into the role of self and social identity in inter-group interaction and behavior by analyzing variables that explain individual and/or collective interaction.

These theories explain how contact changes negative attitudes and stereotypes and demonstrate how attitudinal change can promote peaceful social relations. In engaging with individual perceptions, they emphasize how improved mutual understanding can challenge and overcome prejudice. ${ }^{40}$ However, these theories quite clearly grasp that knowledge about the other is a necessary, but not a sufficient, condition for positive contact. This was recognized from an early stage: Allport's contact hypothesis theory,

${ }^{31}$ The EU Partnership for Peace Program's 2015 Guidelines set out a clear set of aims, which establish that P2P initiatives should: (1) Promote civil society peace-building and conflict transformation actions through initiatives that are likely to impact on people's everyday lives and attitudes: (2) Support practical actions aiming at building mutual trust through reconciliation, thereby building capacity for non-violent approaches to conflict resolution, promoting tolerance, combatting incitement to violence, empowering marginalised parties and launching joint development actions and strategies; (3) Strengthen direct civil society relationships, further enhance forms of co-operation grounded within equality and reciprocity and bring Palestinians and Israelis together. Available at: https://cdn5-eeas.fpfis.tech.ec. europa.eu/cdn/farfuture/D5Q-duWanuhAaN7GgLlCWQO4N6V9zTybx1_sdi4Git8/mtime:1476870254/ sites/eeas/files/eupi-eupfp-programme-at-a-glance-2016_en.pdf, accessed November 22, 2018.

${ }^{32}$ Alliance for Middle East Peace. US Annual People-to-People Funding. Available online at: http://www. allmep.org/u-s-annual-people-to-people-funding/, accessed July 23, 2018.

${ }^{33}$ NGO Monitor (2016) Israeli Committee against House Demolitions (ICAHD). Available at: http:// www.ngo-monitor.org/ngos/israel_committee_against_house_demolitions_icahd_/, accessed September $10,2017$.

${ }^{34}$ Gordon Allport (1954) The Nature of Prejudice (Reading, MA: Addison-Wesley).

${ }^{35}$ Stuart Cook (1962) The Systematic Analysis of Socially Significant Events: A Strategy of Social Research, Journal of Social Issues, 18, pp. 66-84.

${ }^{36}$ Yehuda Amir (1969) The Contact Hypothesis in Ethnic Relations, Psychological Bulletin, 71 (5), pp. 319-342.

37 Thomas Pettigrew (1971) Racially Separate or Together?(New York: McGraw-Hill)

${ }^{38}$ Henri Tajfel (1974) Social Identity and Intergroup Behavior, Social Science Information, 13, pp. 65-93.

${ }^{39}$ H. Tajfel \& John Turner (1979) An integrative theory of intergroup conflict, in: William G. Austin \& Stephen Worchel (eds) Social Psychology of Intergroup Relations, pp. 33-37 (Monterey, CA: Brook/Cole).

${ }^{40}$ Allport, The Nature of Prejudice; Thomas Pettigrew, Racially Separate or Together?; Walter G. Stephan \& Cookie White Stephan (1984) The role of ignorance in intergroup relations, in Norman Miller \& Marilynn Brewer (eds) Groups in Contact: The Psychology of Desegregation, pp. 281-302 (Orlando FL: Academic). 
to take an important example, emphasized that effective contact only could occur if certain situational conditions were met (e.g., equality of status, intimate relations, common goals and institutional support). ${ }^{41}$

Criticism of the P2PP tended to focus on the conditions of contact and the assessment criteria. ${ }^{42}$ This is reflected in the fact that many contributors are predisposed to engage within a 'problem-solving' framework. ${ }^{43}$ Other, more critically orientated observers, instead highlight, to take one example, the gap that divides the donor agenda and NGO priorities. ${ }^{44}$ Palestinian participants highlighted divergences between the two groupings. ${ }^{45}$ Palestinian participants also frequently cited the wider political conditions (power imbalances, restrictions on movement, closures and the fragmentation of Palestinian territory) as ongoing concerns. ${ }^{46}$

These opinions raise the question of how the P2PP theoretically ought to be engaged. First, it is essential to begin with the observation that the P2PP initiated 'subtle' forms of power, which operated through and within the agency of its participants. To borrow Gramsci's formulation, it originated forms of power that were 'half man, half beast. ${ }^{47}$ Gramsci also provides insight into the limits of hegemony. In applying Gramsci to the P2PP, I will explore and develop hegemony, consent and war of position, ${ }^{48}$ thereby providing insight into themes of agency and resistance.

Gramsci's analysis of civil society also has a direct relevance for P2PP. His multidimensional account of power has several potential applications. He is concerned with 'the entire complex of practical and theoretical activities with which the ruling class not only justifies and maintains its dominance, but [also] manages to win the active consent of those over whom it rules. ${ }^{49}$ Gramsci's analysis of hegemony makes it possible to take the concept apart and situate it in a wider context. This is particularly important as it resists the temptation to concentrate power, or to equate it with particular forms, and does not equate 'power' with the ability to coerce. It is important to note that the P2PP

${ }^{41}$ Allport, The Nature of Prejudice.

${ }^{42}$ The Palestine-Israel Journal previously engaged a number of these issues in its 2000 and 2005/06 issues. See 'Reflections on Joint Israeli-Palestinian Cooperation Projects', Palestine-Israel Journal of Politics, Economics and Culture, 7(1-2) (2000) and People-to-People: What Went Wrong and How to Fix It?, Palestine-Israel Journal of Politics, Economics and Culture, 12-13(4) (2005-06).

${ }^{43}$ Lena Endresen (2001) Contact and Cooperation: The Israeli-Palestinian People-to-People Program (Oslo: Institute for Applied Social Science), p. 22

${ }^{44}$ Mohammed Shadid \& Caroline Qutteneh (2000) Palestinian Governmental NGO Relations: Cooperation and Partnership: Proceedings of the International Conference, February 16, 2000 (Ramallah: Welfare Association Consortium); and Dan Bar-On and Sami Adwan (2000) PRIME's Role in Supporting the Collaboration of Palestinian and Israeli NGOs, in: Sami Adwan and Dan Bar-OnBeit (eds) The Role of Non-Governmental Organizations in Peace-Building Between Palestinians and Israelis, pp. 68-72 (Beit Jala: PRIME Publications)

45 Ibid.

${ }^{46}$ Ifat Maoz (2000) Issues in Grassroot Israeli-Palestinian Cooperation: A Report on the NGO Discussion Panels, in ibid, pp. 63-67.

${ }^{47}$ Robert W. Cox (1996) Gramsci, Hegemony, and International Relations: An Essay in Method, in: R. Cox (ed.) Approaches to World Order, pp. 124-143 (Cambridge: Cambridge University Press).

${ }^{48}$ Quintin Hoare \& Jeffrey Nowell-Smith (eds) (1971) Selections from the Prison Notebooks of Antonio Gramsci, p. 495 (New York: International Publishers); \& R. Cox (1983) Gramsci, Hegemony and International Relations: An Essay in Method, Millennium: Journal of International Studies, 12(2), p. 165.

49 Ibid, p. 244. 
did not cancel or deny the agency of local actors; rather, Palestinian participation was the means through which power was enabled and reproduced.

Similarly, Michel Foucault analyzed forms of power that operate through and within freedom and autonomy. Foucault viewed freedom as an essential accompaniment of power rather than its point of denial. As Gramsci emphasized, the education system plays a crucial role in this respect. A 2015 study by Nadia Naser-Najjab and Ilan Pappé examining how international donors had engaged with allegations of incitement within Palestinian school textbooks, brought out this point in more detail. The authors observed that the framework of engagement delegitimized Palestinian narratives of resistance and struggle and lent a spurious legitimacy to practices of occupation. ${ }^{50}$

In common with Foucault, Gramsci also made use of the concept of the 'social,' with the intention of underlining how hegemony extends to 'everyday' social interactions. ${ }^{51}$ Gramsci breaks with the assumption that the formal political sphere and power are synonymous and, in so doing, shatters the misconception that civil society is apolitical, that it exists in serene detachment from venal and debased political passions. Any strategy of resistance, by implication, would need to begin with the insight that the beliefs, principles and values of the ruling class are dispersed throughout society. By implication, any strategy that began with the misconception that power is concentrated ultimately would come up against its own conceptual and practical limitations.

Consequently, internationally sponsored civil society initiatives situate Palestinian society as both the object (to be transformed) and the subject (the means through which transformation is to be enabled and perpetuated) of reform. Far from being contradictory, this ostensible paradox is intrinsic to what Foucault termed 'liberal technologies of government,' that is, practices and techniques that insert and apply control through the modality of freedom. This is achieved through partnership based on claimed equality and even-handedness. The P2PP adopts the discourse of peace and reconciliation while ignoring the colonial reality. This is an example of how 'participation' and 'equality' come to function as means through which colonial relations are reproduced. Palestinians thereby become 'partners' in the reproduction of external knowledge and practices. ${ }^{52}$

According to Foucault "'Government" did not refer only to political structures or to the management of states; rather, it designated the way in which the conduct of individuals or of groups might be directed... To govern, in this sense, is to structure the possible field of action of others. ${ }^{53}$ This outline also can be applied to Selby's discussion of water usage and distribution. He states: '[F]ormalisation of Israeli-Palestinian cooperation had enabled Israel to divest itself of some of the most onerous burdens of occupation, without losing control of either water resources or supplies to Israeli settlements, and without having to forego its discriminatory pricing policy. ${ }^{, 54}$

As with any system of power, it is essential not to take our object of analysis at its own level of justification - that is, as complete or enveloping. Rather, it is essential to

\footnotetext{
${ }^{50}$ Nadia Naser-Najjab \& Ilan Pappé (2015) Reframing Palestine in the Post-Oslo period, in: Robert Guyver (ed.) Teaching History and the Changing Nation States: Transnational and International Perspectives, pp. 9-29 (London: Bloomsbury Academic Publications).

${ }^{51}$ Gramsci, Prison notebooks, p. 244.

${ }^{52}$ Nadera Shalhoub-Kevorkian (2015) Security Theology: Surveillance and the Politics of Fear (Cambridge: Cambridge University Press), p. 6.

${ }^{53}$ Michel Foucault (1982) The Subject and Power, Critical Inquiry, 8(4), p. 790.

${ }^{54}$ Jan Selby (2003) Dressing up Domination as 'Cooperation': The Case of Israeli-Palestinian Water Relations, Review of International Studies, 29 (1), p. 31.
} 
remain alert to points of potential subversion and negotiation. That is, we should resist the temptation to fetishize power, as this article acknowledges by reasserting that the strategies or tactics of subaltern resistance are just as worthy of attention (and in the Palestinian context, this implies a closer engagement with 'hidden transcripts' and 'hidden' or 'symbolic resistances.' ${ }^{55}$ )

In one example of 'veiled resistance,' Palestinian participants made clear that they only had engaged with the P2PP in order to pursue personal benefit and national interest. A participant in a project I helped to coordinate said: 'I am bored because I'm not allowed to travel. I love to go to the sea, so this project gave me the opportunity to visit entertaining places like Tel Aviv. ${ }^{56}$ Other Palestinians said that they had no intention of recognizing, much less working with, the P2PP objectives. According to one participant, 'Israelis tried to contact me for social and personal meetings. I did not meet with them on that basis. That was not my objective. ${ }^{57}$ A similar disregard also was shown toward legal requirements: during one Jerusalem event, participants refused to obtain the required permit for a Jerusalem meeting because they considered it part of the West Bank and the Palestinian state; instead, they sought to access the city through a series of side roads.

This attitude reflected the fact that travel arrangements and negotiation of the permit system were an important part of the asymmetry. ${ }^{58}$ Palestinian participation was to this extent conditional on 'good conduct.' Lee Perlman, an Israeli coordinator, acknowledged:

I believe that the issue of permits was very dehumanising for the Palestinians, and it certainly had a terrible impact on the dignity of the Palestinians. A Palestinian who had spent from two to six hours to obtain the permit would come very angry to the meeting. Thus, [the] first activity was always connected to what happened with the permits. ${ }^{59}$

Perlman added:

Before arriving at Ramallah, I made sure to call the Israeli army and inform them that we would be there and give them a list of the names and identity numbers of all the participants. This was for two reasons: One psychological and one organisational as part of our responsibility and policy. ${ }^{60}$

The P2PP's detachment from reality and its inability to take power relations into consideration resulted in Palestinian objections and criticisms. ${ }^{61}$ As a Palestinian participant observed:

\footnotetext{
${ }^{55}$ James C.Scott (1990) Domination and the Arts of Resistance: Hidden Transcripts (London: Yale University Press e-book). Available at: http://www.jstor.org/stable/j.ctt1np6zz, accessed February 26, 2017; and Markus Bouillon (2004) Gramsci, Political Economy, and the Decline of the Peace Process, Critique: Critical Journal of Middle East Studies, 13(3), pp. 239-264.

${ }^{56}$ Author Interview, Ramallah, August 18, 2001.

${ }^{57}$ Author Interview, Ramallah, September 7, 2001.

${ }^{58}$ Ifat Maoz (2004) Peace Building in Violent Conflict: Israeli-Palestinian Post-Oslo People-to-People Activities, International Journal of Politics, Culture, and Society, 17(3), pp. 563-565.

${ }^{59}$ Author Interview, Lee Perlman, Londonderry, Northern Ireland, June 29, 2001.

${ }^{60}$ Ibid.

${ }^{61}$ Nadim Rouhana (2004) Group Identity and Power Asymmetry in Reconciliation Processes: The IsraeliPalestinian case, Peace and Conflict, pp. 41-22.
} 
One time, we were in one of the villages [as part of the P2PP], and they were distributing a publication on how to use water and economize in use of water, and one woman asked me a question: I cannot imagine how an Israeli is coming here to educate me on how to use water while I still use the bucket and close to me there is a settlement where they have swimming pools, so how an Israeli comes to educate me on how to use water and they are occupying our land? The Israeli institution working with you should work inside the Israeli society and not educate me. ${ }^{62}$

Critical contributions to the peace-building literature also have a clear relevance to the P2PP. Much of the preceding analysis is concisely summarized by Oliver Richmond, who saw a clear danger 'that top-level actors will instil in the system their own biases and interests, while arguing that they are constructing a universal system. Any universal peace system is therefore open to being hijacked by hegemonic actors. ${ }^{63}$ Richmond's allusion to 'biases and interests' implicitly invokes the hegemonic system of neo-liberal capitalism. ${ }^{64}$ This again demonstrates how a disciplinary or regulatory set of techniques can become equated with an emancipatory project that aspires to social transformation and the concrete realization of various freedoms. As Richmond illustrates, this conflation has been profoundly negative, resulting in innumerable discursive and conceptual enclosures and the origination of a 'form [of peace] that is so ontologically solid that no debate is required. ${ }^{65}$ Richmond's reading of neoliberal peace building presents an emaciated and insubstantial form that has been comprehensively divested of its emancipatory or transformative potential.

Richmond's critique is clearly relevant to the Palestinian case. Here peace-building has given way to state-building, a project closely aligned with elite interests and wider systemic preferences. ${ }^{66}$ As Richmond repeatedly has iterated, the proposition that the sterile axioms of 'good governance' can sustain peace is a classically liberal conceit. This shift also singly fails to acknowledge that peace is, in the Palestinian context, essentially a precondition. The protracted failure of the peace process therefore originates in a prior conceptual limitation rather than a practical application. Raja Khalidi and Samour Sobhi make this point: "The statehood program encourages the idea that citizens may have to acquiesce in occupation but will not be denied the benefits of smoother running traffic, a liberal education curriculum, investor-friendly institutions [and] efficient public service delivery. ${ }^{67}$ The displacement of peace-building by statebuilding provides one illustration of how external donors seek to reframe the terms of engagement, while subtly orientating the respective actors toward their own interests, preferences and political discourse. ${ }^{68}$

\footnotetext{
${ }^{62}$ Jerusalem Media and Communication Center (JMCC) (2006) Palestinian-Israeli Public Debate on People-to-People Program: An Evaluation, p. 21 (Jerusalem: JMCC).

${ }^{63}$ Oliver P. Richmond (2007) Critical Research Agendas for Peace: The Missing Link in the Study of International Relations, Alternatives, 32(2), p. 258.

${ }^{64}$ Ibid, p. 261.

${ }^{65}$ Ibid, p. 250.

${ }^{66}$ Haddad, Palestine Ltd, p.138.

${ }^{67}$ Raja Khalidi \& Samour Sobhi (2011) Neoliberalism as Liberation: The Statehood Programme and the Remaking of the Palestinian National Movement, Journal of Palestine Studies, 40(2), p. 15; and Bouris (2010) The European Union's Role in the Palestinian Territory after the Oslo Accords: Stillborn Statebuilding, p. 380.

${ }^{68}$ Haddad, Palestine Ltd; and Shir Hever (2017) The Political Economy of Israel's Occupation: Repression beyond Exploitation (London: Pluto Press).
} 
The vernacular of 'capacity-building', so beloved by international practitioners, creates the clear impression that the end aspiration is a political institution that is able to operate independently of external influence. However, this conceals the essential point that the 'weakness' of the Palestinian Authority has a clear functional benefit: The PA's deeply ingrained weakness and dependency ${ }^{69}$ is not just an inadvertent aftereffect, but instead an intended design component, conceived as a means through which external forms of 'discipline' could be more completely embodied and realized. This article adapts this insight to suggest that both the general framework (Oslo Accords) and specific mechanism (the P2PP) can be interpreted as instruments that subtly discipline and regulate the domestic context, while aligning it with external preferences. ${ }^{70}$

\section{Hegemony and Consent}

It is essential to acknowledge that the participants did not engage under conditions or terms of their own choosing. While 'participation' was openly solicited and celebrated by the P2PP, closer inspection revealed that participation only could occur within certain limitations and constraints. This is clearly indicated by the depoliticized character of the P2PP. It was not an accidental or inadvertent feature, but was quite clearly anticipated in the P2PP design and intention.

Planning groups zealously monitored project content, taking care to ensure that political content was not allowed to creep in (although this was part of the P2PP design, Palestinian political representatives also had a clear vested interest in ensuring that their own interests remained immune from political challenge or contestation). ${ }^{71}$ From the outset, this created a clear contradiction, or tension, as many Palestinians engaged with the P2PP with explicitly political ends and purposes in mind: A large majority saw the P2PP as a means through which Israelis could be 'educated' and 'enlightened' about the realities of occupation.

Gramsci also makes an invaluable contribution by highlighting that consent and control are not diametric opposites; rather, the former is, in many respects and instances, a precondition for the latter. Upon engaging with the $\mathrm{P} 2 \mathrm{PP}$, the respective participants consented to a framework of engagement that sought to structure and reorder their own agency - it quite explicitly sought to challenge, alter and reconfigure the terms upon which they engaged with the Palestinian-Israeli conflict. This consent was not self-sustaining, but instead was prefigured by a system of enticements. As Gramsci observed, consent to hegemony is related to its associated benefits or rewards. Therefore, and although criticism of the P2PP was pronounced from the outset, no decisive steps were taken.

As early as June 1995, participants had begun to voice concerns on these and other issues. In my role as a coordinator for Al-Jiser, a Palestinian NGO, I arranged an internal meeting which brought together 35 Palestinian participants in total (including directors and staff members from 20 different NGOs). During the meeting, a number of speakers voiced concern that the lack of a Palestinian strategy was contributing to a

\footnotetext{
${ }^{69}$ Khalidi, The Iron Cage, pp. 172-181.

${ }^{70}$ Robert W. Cox (1996) Gramsci, Hegemony, and International Relations: An Essay in Method, in: R. Cox (ed.) Approaches to World Order, pp. 124-143 (Cambridge: Cambridge University Press), p. 138; and Haddad, Palestine Ltd.

${ }^{71}$ Endresen \& Gilen, Consultation and Consensus.
} 
situation in which Israeli NGOs worked around their 'partners' (often by engaging with individuals in a personal capacity), enabling them to impose their own agenda upon 'joint' projects.

The meeting succeeded in outlining a clear agenda. In addition to clarifying that dialogue should be a means to an end (rather than an end in and of itself), it also established the need for a unified Palestinian strategy; improved training and capacitybuilding; enhanced institutional oversight of the P2PP; clarification of the legal status of Palestinian NGOs; development of a unified funding agency policy; and a 'reaching out' to wider Israeli and Palestinian public opinion. ${ }^{72}$

Their efforts in this respect did not, however, elicit the anticipated response. One Israeli participant complained: 'Palestinians are so busy showing us their misery and expecting us to be one-sided, on their side.' Another Israeli participant criticized the Palestinian tendency to present their cause while refusing to take responsibility for their situation. Israelis, for their part, viewed the P2PP as an opportunity to break with the past and open a new chapter in Israeli-Palestinian relations. This was embodied in one Israeli assertion that the 'past does not help with the future.' For Palestinians, however, the past overshadows the present. As one participant said:

In one case a Palestinian brought along a manual coffee grinder as an example of Palestinian culture. One Israeli participant commented that he had not seen this mill before. The Palestinian answered that he (the Israeli) must have seen it abandoned in one of the houses taken over by Israelis in $1948 .^{73}$

Given that their motivations so transparently diverged from the outset, it was perhaps unsurprising that several meetings broke up in acrimonious circumstances. According to Abu Saad, 'the dominant group tended to know only its own understanding of reality and social relations because it had ignored, rejected, and silenced the differing perspectives of those over whom it had power. ${ }^{74}$ It was also noticeable that the 'peace' discourse was deployed in a manner that silenced Palestinian narratives. Foucault previously had described the institutional control and deployment of discourse. ${ }^{75}$ The example of the P2PP shows how the Israeli state succeeded in co-opting and instrumentalizing the peace discourse.This proved to be particularly frustrating for Palestinian participants, as their interpretations of peace were marginalized by 'rules of exclusion. ${ }^{76}$ But Foucault made clear that this discourse could be contested: 'discourse is the thing for which and by which there is struggle, discourse is the power which is to be seized. ${ }^{77}$ It was perhaps unproductive to expect donors to resolve these issues, as to some extent they were actually the problem. For example, I repeatedly encountered the objection that donors viewed Palestinians as inferior and lacking in the capabilities (administrative, logistical, etc.) that would enable them to contribute to the P2PP.

\footnotetext{
${ }^{72}$ Al-Jiser (1995) Palestinian Meeting for People Concerned with Joint Activities with Israelis. Unpublished paper (Jerusalem: Al-Jiser).

73 Author Interview, Ali Haseeb, Ramallah, January 29, 2004.

${ }^{74}$ Abu Saad, 'Where Enquiry Ends,' p. 1906.

${ }^{75}$ M. Foucault (1984) The Order of Discourse, in: M. Shapiro (ed.) Language and Politics, I. McLeod (trans.), p. 110.

${ }^{76}$ Ibid, pp. $108-138$

${ }^{77}$ Ibid, p. 110.
} 
Whenever these complaints were voiced, I always thought of Edward Said's Orientalism, and the accumulated cultural, political and historical baggage that predisposes many Americans and Europeans to view Arabs as 'child-like' and culturally inferior. While it would be easy to exaggerate these concerns, it was clear that Orientalist attitudes had not disappeared. Given that the P2PP was predicated on the equality of all participants, it was more than a little surprising that some international donors saw no issue with Israeli NGOs assuming a mentoring role or assuming sole responsibility for financial management (on the grounds that their Palestinian counterparts might 'misuse' funding).

Philip Veerman, the director of Defence for Children International-Israel (DCIIsrael) provided a particularly insightful example: His NGO, in partnership with the Palestinian Counselling Center (PCC), had submitted an application to a prominent American donor agency. After the application successfully went through successive assessment phases, DCI-Israel received a letter that suggested that it would be appropriate for it to assume responsibility for financial oversight and reporting. Veerman was uncomfortable with the proposed arrangement, and was fully aware that potentially it could complicate relations with the PCC. Separate conversations with other NGOs persuaded me that this was not an isolated incident, but was instead indicative of a deeply rooted mindset. ${ }^{78}$

This point was brought home with renewed force during an interview with Sarah Ozacky-Lazar, the director of Givat Haviva/the Jewish-Arab Center for Peace. ${ }^{79}$ I was astonished to learn that even activities and courses focused on the empowerment of Palestinian society sometimes were run and administered by Israeli NGOs. In discussing the EU's funding arrangements, Ozacky-Lazar also acknowledged the pervasive concern that Palestinian NGOs might reassign or otherwise misuse allocated funds. This asymmetry was not an unfortunate or contingent feature but was instead entrenched within the very fabric of the peace process.

It is clear that a considerable portion of blame also can be apportioned to Palestinian NGOs, which consistently evidenced an inability to outline and adhere to a collective stance. At this juncture, Palestinians still calculated that consent would elicit the anticipated benefits. A specific example helps to reiterate this point. In 1999, three participating NGOs (the Finnish Citizens' Security Council [KATU], the Palestinian Centre for Peace [PCP] and the Economic Co-operation Foundation) arranged an evaluative Workshop on the Israeli-Palestinian Civil Society-Cooperative Activities, which brought together donor representatives and Palestinian, Israeli and European NGOs. During the course of the workshop, familiar concerns were raised and discussed. However, the final letter of recommendation did not reflect the content of these discussions, and instead called for continued funding. ${ }^{80}$ Even taking into account the possibility that Palestinian contributors were seeking to subvert the established agenda in more subtle or covert ways, it seems unusual that this opportunity was passed over in favor of a bland reiteration of the P2PP's core aims: 'We emphasize

\footnotetext{
${ }^{78}$ See further Sami Adwan \& Philip Veerman (2000) Reflections on Joint Israeli-Palestinian Cooperation Projects, Palestine-Israel Journal of Politics, Economics and Culture, 7(1-2), pp. 89-96.

79 Author Interview, Sarah Ozacky-Lazar, Jerusalem, August 28, 2001.

${ }^{80}$ KATU-Helsinki (1999) Declaration of Recommendation to Donors Supporting the Israeli-Palestinian Civil Society-Cooperative Activities: Report of the Workshop on the Israeli-Palestinian Civil Society Cooperative Activities, November 27-28 (Helsinki: KATU-Helsinki).
} 
the need to enable the expansion of the people-to-people activities to reach a critical mass of Israelis and Palestinian citizens, particularly those who are not fully supportive of the peace process and those who are moderately opposed to it. ${ }^{81}$

\section{The P2PP after the Second Intifada: The Limits of Hegemony}

While concerns and grievances continued to accumulate during the P2PP, it should be acknowledged that, from the outset. Palestinians had been far from enthusiastic about engaging with the P2PP. Issa Rabadi of IPCRI, a co-director of a peace education project, explained: 'I feel I have to explain myself and state that I do not work on normalisation. I tell people that I want to serve my cause and raise the awareness of the Palestinian identity through a peace education program. People are usually sarcastic about the work with Israelis. ${ }^{, 82}$

This attitude embodies the Palestinian concern that participation in the P2PP would be conflated with normalization. Israelis who participated in the P2PP often made precisely this conflation, and assumed that, as a peace process was in operation, Palestinians and Israelis could now engage on 'normal' terms. ${ }^{83}$ This was not the case, and Palestinians gradually became resistant to joint projects that did not have, as their stated goal, 'resistance to and exposure of the Israeli occupation and all forms of discrimination and oppression against the Palestinian people.'

By 2000 grievances had accumulated to the point where payment was a necessary condition of continued Palestinian engagement. These financial benefits often proved to be sufficient to overcome deeply rooted objections. This perhaps helps to explain why there was no Palestinian consensus on a total boycott prior to the outbreak of the Second Intifada in 2000. The militarization of the Intifada and grossly unequal power relations ultimately convinced Palestinian civil society that a more decisive way of resistance was an appropriate response. While various evaluations were undertaken, Palestinian dissatisfaction with the P2PP continued to accumulate, peaking just prior to the outbreak of the Second Intifada. After the uprising erupted in September 2000, the General Assembly of the Palestinian NGO Network (PNGO) responded by setting out its position in a press release, which called on Palestinian and Arab NGOs to conclude all joint projects (particularly $\mathrm{P} 2 \mathrm{P}$ projects), and asserted that any future cooperation should be made conditional upon the recognition of full Palestinian rights including the right of return. ${ }^{84}$ This brings to mind Gramsci's 'war of position, ${ }^{85}$ which Cox defines as "the creation of "alternative institutions and alternative intellectual resources within existing society.", 86

\footnotetext{
${ }^{81}$ Ibid, p. 1 .

${ }^{82}$ Author interview, Issa Rabadi, Jerusalem, December 15, 2003.

${ }^{83}$ Manuel Hassassian (2000) The Role of Palestinian NGOs in Peace Building and Conflict Resolution, in: Sami Adwan and Dan Bar-On (eds) The Role of Non-Governmental Organizations in PeaceBuilding Between Palestinians and Israelis, p. 29 (Beit Jala: PRIME Publications)

${ }^{84}$ The PNGO, however, made clear that it was willing to engage with Israeli organizations that recognized these national rights. It stated: 'These decisions do not conflict with the principle of cooperation with any activity held by the Israeli Human Rights Associations to support the Palestinian nation in its struggle for liberation and the establishment of a Palestinian state, and to declare their support for a fair and durable peace.' (PNGO, 2000: www.pngo.net), accessed February 24, 2004

${ }^{85}$ Gramsci, Prison notebooks, p. 495.

${ }^{86}$ Cox, Gramsci, Hegemony and International Relations, p. 165.
} 
Some Israeli NGOs sought to address and engage Palestinian grievances. Bat Shalom, an Israeli feminist NGO, submitted a message for the Palestinian people to Al-Quds, which the newspaper published on March 25, 2001. This message reiterated the Israeli government's responsibility to resolve the Palestinian refugee issue, anticipated the dismantling of 'the apparatus of occupation' and sought an ongoing solidarity between voices of 'peace, coexistence and cooperation in the Middle East. ${ }^{87}$

After a 2004 ruling by the International Court of Justice (ICJ) declared the wall to be illegal, Palestinian civil society began to mobilize under the banner of the Boycott, Divestment and Sanctions (BDS) movement, which gained particular impetus. This development is not surprising, as it is quite transparent that BDS addresses the root cause of the conflict (the colonization and the denial of Palestinian rights). Proceeding in accordance with Gramsci's 'war of position,' BDS sought a 'decisive' victory. Some civil society organizations then sought to dissociate themselves fully from joint initiatives. In 2005, for example, the Palestinian health sector published 'An Open Letter to the Palestinian and International Community Regarding Palestinian-Israeli Cooperation in Health,' which set out a number of clear objections to joint projects. ${ }^{88}$

However, BDS did not reject contact that sought to change political reality by forcing the collapse of the colonial structure. ${ }^{89}$ The First Intifada, when Palestinians and Israelis jointly participated in action-based, non-violent resistance, is an important historical example in this respect. Joint protests against the wall at Bil'in provide a more recent contemporary example. ${ }^{90}$ Here the power relation explicitly is acknowledged and targeted, and Palestinians are the 'empowered' subjects leading genuinely popular resistance in opposition to colonialism.

In January 2004, the P2PP was halted following the election of a Likud government led by Ariel Sharon, which decided to withdraw from the P2PP. ${ }^{91}$ In the absence of a broad consensus on P2PP, donors nonetheless have continued to fund P2PP activities. Ongoing evaluations also continue to seek improved implementation. However, as the political situation continued to deteriorate, Palestinians adopted a stronger position on P2PP, and this underlines the limits of hegemony. The benefits offered by donors were, by that stage, insufficient to ensure continued Palestinian engagement. Consequently, in April 2005, international donors arranged a joint conference with the aim of evaluating previous P2P projects. In a clear nod to Palestinian concerns, the conference agenda explicitly registered the importance of power relations and the wider political context. Dominique Rosetti, a member of the Canadian Representative Office to the PA, also acknowledged that Israeli NGOs were, in comparison to their

\footnotetext{
${ }^{87}$ Bat Shalom (2004) A Public Letter to the Palestinian People. Available at: www.batshalom.org, accessed March 12, 2004.

${ }^{88}$ Palestinian Committee for the Academic and Cultural Boycott of Israel (BDS) (2005) An Open Letter to the Palestinian and International Community Regarding Palestinian-Israeli Cooperation in Health. Available at: http://www.monabaker.com/pMachine/more.php?id=2903_0_1_84_M5, accessed September 10, 2017.

${ }^{89}$ PACBI Statement (2011) Israel's Exceptionalism: Normalizing the Abnormal, October 31. Available at: https://bdsmovement.net/news/israel $\% \mathrm{E} 2 \% 80 \% 99$ s-exceptionalism-normalizing-abnormal, accessed January 21, 2017.

${ }^{90}$ Mazin B. Qumsiyeh (2016) A Critical and Historical Assessment of Boycott, Divestment, and Sanctions (BDS) in Palestine, in: Alpaslan Ozerdem, Chuck Thiessen \& Mufid Qassoum (eds) Conflict Transformation and the Palestinians (Florence: Taylor and Francis).

${ }^{91}$ Author Interview, Akram Attalla, Jerusalem, February 19, 2004.
} 
Palestinian counterparts, better funded and possessed clear technical and administrative advantages. $^{92}$

The conference concluded that a lack of consensus within both societies inhibited attempts to broaden participation within the P2PP. It also observed that the wider political context should be acknowledged at all stages of project design, implementation and evaluation.

In July 2006, the Norwegian Representative Office to the PA helped to fund a public debate, which addressed itself to evaluating P2P activities and developing suitable participant guidelines. In attempting to work around Israeli closures, they also arranged parallel workshops, which produced a clear consensus on several important issues. Firstly, there was general acknowledgement that the P2PP had failed to engage sufficiently and to penetrate either Israeli or Palestinian society. Secondly, Palestinian contributors highlighted the gulf between Palestinian and donor priorities and complained that donor interventions had advantaged Israeli NGOs; in their view, this further compounded the advantages that Israeli NGOs already enjoyed. ${ }^{93}$ Palestinian contributors were highly critical of the way that 'contact' had been framed in apolitical and procedural terms. In their view, this significantly diminished the legitimacy of Palestinian resistance and the central significance of Palestinian political rights. ${ }^{94}$

\section{Conclusion}

This article has sought to develop a critical analysis of the P2PP, with a view to linking it to broader strategic interests and priorities by adapting and applying Gramsci's theoretical lens of 'hegemony.' Rather than focusing on the theoretical conditions for effective contact, I instead situated the P2PP within the wider power relations that circulated during the Oslo era. ${ }^{95}$ From the outset, the P2PP was undermined by broader political developments, and consequently failed to live up to its initial expectations. Its designers began with precisely the opposite expectation, namely that the P2PP would create positive wider momentum by helping to construct a peace 'from below.' However, far from establishing a basis for reconciliation, the P2PP became a cause of division, and many Palestinian participants became disillusioned and ultimately disengaged from the process.

The Gramscian framework helps us to understand better how Palestinians sought to resist the hegemony of the internationally-imposed agenda of neoliberal state building. It also draws out features of Palestinian resistance, such as the BDS movement, which has grown in stature and confidence. Within Israel, the administrators of occupation have viewed it with trepidation and concern, even to the point of perceiving it as an existential threat to Israel. However, I suggest that BDS ought to be viewed as an outgrowth of the general development of P2PP. In observing the P2PP through this lens, I

\footnotetext{
92 Dominique Rosetti (2005/06) Peace-building Programmes: A Canadian View. A new Canadian Project for the Advancement of Peace, Palestine-Israel Journal of Politics, Economics and Culture, 12-13(4), p. 64.

93 Jerusalem Media and Communication Center (JMCC) (1996) Israeli-Palestinian Interim Agreement on the West Bank and the Gaza Strip (1995) (Washington DC: Occasional Document Series No. 7, August).

94 Ibid.

${ }^{95}$ Bouillon, Gramsci, Political Economy and the Decline of the Peace Process, p. 242.
} 
came to view BDS as accentuating its limitations and progressing beyond them. In this regard, BDS articulates the distinctive tenor and vernacular of Palestinian struggle.

\section{Acknowledgments}

I thank the Institute of Arab and Islamic Studies, University of Exeter for encouragement and support. I thank the anonymous referees for their constructive comments. I am grateful for Dr. Emile Badarin, postdoctoral research fellow at the European Neighbourhood Policy (ENP) Chair, College of Europe, Natolin, for the valuable suggestions and insightful feedback.

\section{Disclosure statement}

No potential conflict of interest was reported by the author.

\section{References}

Abu-Saad, I. (2008) Where Inquiry Ends: The Peer Review Process and Indigenous Standpoints, American Behavioral Scientist, 51(12), pp. 1902-1918.

Adwan, S., \& Veerman, P. (2000) Reflections on Joint Israeli-Palestinian Cooperation Projects, PalestineIsrael Journal of Politics, Economics and Culture, 7(1-2), pp. 89-96.

Alfred, T. (2005) Wasáse: Indigenous Pathways of Actions and Freedom (Ontario: Broadview Press).

Al-Jiser (June 1995) Palestinian Meeting for People Concerned with Joint Activities with Israelis (Unpublished paper) (Jerusalem: Al-Jiser)

Alliance for Middle East Peace (n.d.) U.S. Annual People-to-People Funding. Available at: http://www. allmep.org/u-s-annual-people-to-people-funding/, accessed July 23, 2018.

Allport, G. (1954) The Nature of Prejudice (Reading, Massachusetts: Addison-Wesley).

Amir, Y. (1969) The Contact Hypothesis in Ethnic Relations, Psychological Bulletin, 71(5), pp. 319-342.

Badarin, E. (2015) Settler-Colonialist Management of Entrances to the Native Urban Space in Palestine, Settler Colonial Studies, 5(3), pp. 226-235.

Bar-On, D., \& Adwan, S. (2000) PRIME's Role in Supporting the Collaboration of Palestinian and Israeli NGOs, in: Adwan S. \& Bar-On (eds) The Role of Non-Governmental Organizations in Peace-Building Between Palestinians and Israelis, pp. 68-72 (Beit Jala, West Bank: PRIME Publications).

Bar-On, M. (1996) In Pursuit of Peace: A History of the Israeli Peace Movement (Washington, DC: United States Institute of Peace Press).

Bat Shalom (2004) A Public Letter to the Palestinian People. Available at: www.batshalom.org, accessed March 12, 2004.

Bishara, M. (2001) Palestine/Israel: Peace or Apartheid: Prospects for Resolving the Conflict (London: Zed Books)

Bouillon, M. (2004) Gramsci, Political Economy, and the Decline of the Peace Process, Middle East Critique, 13(3), pp. 239-264.

Bouris, D. (2010) The European Union's Role in the Palestinian Territory after the Oslo Accords: Stillborn State-Building, Journal of Contemporary European Research, 6(3), pp. 376-394. Available at: http:// www.jcer.net/ojs/index.php/jcer/article/view/205/232, accessed February 12, 2019.

B'Tselem (2010) By Hook and by Crook: Israel's Settlement Policy in the West Bank, Summary. Jerusalem, July 5 .

Cook, S. W. (1962) The Systematic Analysis of Socially Significant Events: A Strategy of Social Research, Journal of Social Issues, 18(2), pp. 66-84.

Cox, R. (1983) Gramsci, Hegemony and International Relations: An Essay in Method, Millennium: Journal of International Studies, 12(2), pp. 162-175.

Cox, R. (1996) Gramsci, Hegemony, and International Relations: An Essay in Method, in: Cox, R. (ed.) Approaches to World Order, pp. 124-143 (Cambridge: Cambridge University Press). 
Darweish, M.\& Rigby, A. (2015) Popular Protest in Palestine: The Uncertain Future of Unarmed Resistance (London: Pluto Press).

Endresen, L.\& Gilen, S. (2000) Consultation and Consensus: Implementing the Israeli-Palestinian People-toPeople Program for Development, Development, 43(3), pp. 29-33.

Endresen, L. (2001) Contact and Cooperation: The Israeli-Palestinian People-to-People Program (Oslo: Institute for Applied Social Science).

Farsakh, L. (2005) Independence, Cantons or Bantustans: Whither the Palestinian State?, The Middle East Journal, 59(2), pp. 230-245.

Foucault, M. (1982) The Subject and Power, Critical Inquiry, 8(4), pp. 777-795.

Foucault, M. (1984) The Order of Discourse, in: Shapiro, M. (ed.) Language and Politics, pp. 108-138 (New York: The New York University Press).

Ghanem, A. (2010) Palestinian Politics After Arafat: A Failed National Movement (Bloomington: Indiana University Press).

Gramsci, A. (1971) Selections from the Prison Notebooks of Antonio Gramsci, in: Hoare, Q. \& Smith, G. N. (eds) (New York: International Publishers)

Grande, S. (2004) Red Pedagogy: Native American Social and Political Thought (Lanham, MD: Rowman \& Littlefield Publishers).

Haddad, T. (2016) Palestine Ltd: Neoliberalism and Nationalism in the Occupied Territories (London: I B Taurus),

Hammami, R. (1995) NGOs: The Professionalization of Politics, Race \& Class, 37(2), pp. 51-63.

Hanafi, S. (2007) Dancing Tango During Peacebuilding: Palestinian-Israeli People-to-People Programs for Conflict Resolution, in: Kuriansky, J. (ed.) Beyond Bullets \& Bombs: Grassroots Peacebuilding between Israelis and Palestinians, pp. 69-80 (Westport, CT: Praeger).

Hanieh, A. (2016) Development as Struggle: Confronting the Reality of Power in Palestine, Journal of Palestine Studies, 45(4), pp. 32-47.

Hassassian, M. (2000) The Role of Palestinian NGOs in Peace Building and Conflict Resolution, in: Adwan, S. \& Bar-On, D. (eds) The Role of Non-Governmental Organizations in Peace-Building Between Palestinians and Israelis (Beit Jala: PRIME Publications).

Hever, S. (2017) The Political Economy of Israel's Occupation: Repression Beyond Exploitation (London: Pluto Press)

Hilal, J. (2010) The Polarization of the Palestinian Political Field, Journal of Palestine Studies, 39(3), pp. 24-39.

Jerusalem Media and Communication Center (JMCC) (1996) Israeli-Palestinian Interim Agreement on the West Bank and the Gaza Strip (1995) (Washington, DC:Occasional Document Series No. 7, August).

Helsinki, K. (1999) Declaration of Recommendation to Donors Supporting the Israeli-Palestinian Civil Society-Cooperative Activities: Report of the Workshop on the Israeli-Palestinian Civil Society Cooperative Activities, 27-28 November, 1999.

Khalidi, R., \& Sobhi, S. (2011) Neoliberalism as Liberation: The Statehood Programme and the Remaking of the Palestinian National Movement, Journal of Palestine Studies, 40(2), pp. 6-25.

Khalidi, R. (2006) The Iron Cage: The Story of the Palestinian Struggle for Statehood (Boston: Beacon Press).

Kaminer, R. (1996) Politics of Protest: The Israeli Peace Movement and the Palestinian Intifada (Brighton: Sussex Academic Press).

Maoz, I. (2000) Issues in Grassroot Israeli-Palestinian Cooperation: A Report on the NGO Discussion Panels, in: Adwan S. \& Bar-On, D. (eds) The Role of Non-Governmental Organizations in PeaceBuilding Between Palestinians and Israelis, pp. 63-67 (Beit Jala: PRIME Publications).

Maoz, I. (2004) Peace Building in Violent Conflict: Israeli-Palestinian Post-Oslo People-to-People Activities, International Journal of Politics, Culture, and Society, 17(3), pp. 563-574.

Makdisi, S. (2010) Palestine Inside Out: An Everyday Occupation (New York: Norton)

Mu'allem, N. (1999) Palestinian Israeli Civil Society Co-operative Activities, Paper Presented to Workshop Peace Building between Israelis and Palestinians, Helsinki, 27-28 November.

Naser-Najjab, N., \& Pappé, I. (2015) Reframing Palestine in the Post-Oslo period, in: Guyver, R. (ed.) Teaching History and the Changing Nation States: Transnational and International Perspectives, pp. 9-29 (London: Bloomsbury Academic Publications).

NGO Monitor (2016) Israeli Committee against House Demolitions (ICAHD). Available at: http://www.ngomonitor.org/ngos/israel_committee_against_house_demolitions_icahd_/, accessed September 10, 2017. 
PACBI Statement (2011) Israel's Exceptionalism: Normalizing the Abnormal, October 31. Available at: https://bdsmovement.net/news/israel $\% \mathrm{E} 2 \% 80 \% 99$ s-exceptionalism-normalizing-abnormal, accessed January 21, 2017.

Palestinian Committee for the Academic and Cultural Boycott of Israel (BDS) (2005) An Open Letter to the Palestinian and International Community Regarding Palestinian-Israeli Cooperation in Health. Available at: http://www.monabaker.com/pMachine/more.php?id=2903_0_1_84_M5, accessed September 10, 2017.

Palestinian Academic Society for the Study of International Affairs (PASSIA) (2001) Settlements and the Final Status Talks, Special Bulletin, March (Jerusalem/Al-Quds).

Peace Now (2000) Summary Data, 4 December.

Pettigrew, T. F. (1971) Racially Separate or Together? (New York: McGraw-Hill).

Qumsiyeh, M. (2016) A Critical and Historical Assessment of Boycott, Divestment, and Sanctions (BDS) in Palestine, in: Ozerdem, A., Thiessen, C., \& Qassoum, M. (eds) Conflict Transformation and the Palestinians, pp. 89-113 (Florence: Taylor and Francis).

Qumsiyeh, M. (2012) Popular resistance in Palestine: A history of hope and empowerment (London: Pluto Press).

Richmond, O. P. (2007) Critical Research Agendas for Peace: The Missing Link in the Study of International Relations, Alternatives: Global, Local, Political, 32(2), pp. 247-274.

Rouhana, N. (2004) Group Identity and Power Asymmetry in Reconciliation Processes: The IsraeliPalestinian Case, Peace and Conflict: Journal of Peace Psychology, 10(1), pp. 33-52.

Rosetti, D. (2005/06) Peacebuilding Programmes: A Canadian View. A New Canadian Project for the Advancement of Peace, Palestine-Israel Journal of Politics, Economics and Culture, 7(4), pp. 12-13, p.64.

Roy, S. (1995) The Gaza Strip: The Political Economy of De-Development (Washington, DC: Institute for Palestinian Studies).

Scham, P. (2000) Arab-Israeli Research Cooperation, 1995-1999, Middle East Review of International Affairs Journal, (3), pp. 1-16.

Scott, J. C. (1990) Domination and the Arts of Resistance: Hidden Transcripts (London: Yale University Press [e-book]). Available at: http://www.jstor.org/stable/j.ctt1np6zz, accessed October 3, 2017

Selby, J. (2003) Dressing up Domination as 'Cooperation': The Case of Israeli-Palestinian Water Relations, Review of International Studies, 29(1), pp. 121-138.

Shadid, M., \& Qutteneh, C. (2000) Palestinian Governmental NGO Relations: Cooperation and Partnership: Proceedings of the International Conference, February 16 (Ramallah: Welfare Association Consortium).

Shalhoub-Kevorkian, N. (2015) Security Theology: Surveillance and the Politics of Fear (Cambridge: Cambridge University Press).

Shehadeh, R. (1997) From Occupation to Interim Accords: Israeli and the Palestinian Territories (London: Kluwer Law International).

Smith, L. T. (2012) Decolonizing Methodologies (London: Zed Books)

Stephan, W. G., \& Stephan, C. W. (1984) The Role of Ignorance in Intergroup Relations, in: Miller, N. \& Brewer, M. (eds) Groups in Contact: The Psychology of Desegregation, pp. 281-302 (Orlando, FL: Academic).

Tajfel, H. (1974) Social Identity and Intergroup Behavior, Social Science Information, 13, pp. 65-93.

Tajfel, H., \& Turner, J. C. (1979) An Integrative Theory of Intergroup Conflict, in: Austin, W. G. \& Worchel, S. (eds) Social Psychology of Intergroup Relations, pp. 33-37 (Monterey, CA: Brook/Cole).

Weizman, E. (2007) Hollow Land: Israel's Architecture of Occupation (London: Verso Books).

World Bank (2011) Coping with Conflict: Poverty and Inclusion in the West Bank and Gaza (Washington: The World Bank Group).

Zagha, A., \& Zumlot, H. (2004) Israel and the Palestinian Economy: Integration or Containment?, in: Amundsen, I., Giacaman, G., \& Khan, M. H. (eds) State Formation in Palestine: Viability and Governance During a Social Transformation, pp. 120-140 (London: Routledge). 